NBER WORKING PAPER SERIES

\title{
REAL EFFECTS OF THE SUBPRIME MORTGAGE CRISIS: IS IT A DEMAND OR A FINANCE SHOCK?
}

\author{
Hui Tong \\ Shang-Jin Wei \\ Working Paper 14205 \\ http://www.nber.org/papers/w14205
NATIONAL BUREAU OF ECONOMIC RESEARCH
1050 Massachusetts Avenue
Cambridge, MA 02138 \\ July 2008
}

We thank Tam Bayoumi, Stijn Claessens, Marcello Estevao, Laura Kodres, Luc Laeven, Neng Wang, Toni Whited, Olaf Unteroberdoerster, Yishay Yafeh, and seminar and conference participants at the IMF, HKMA, and the International Finance Conference sponsored by Bank of Canada and Queen's University for helpful comments, and John Klopfer, Andrew Swiston, and Natalia Barrera Tovar for excellent research assistance. The views in the paper are those of the authors, and do not necessarily reflect those of the IMF nor those of the National Bureau of Economic Research.

NBER working papers are circulated for discussion and comment purposes. They have not been peerreviewed or been subject to the review by the NBER Board of Directors that accompanies official NBER publications.

(C) 2008 by Hui Tong and Shang-Jin Wei. All rights reserved. Short sections of text, not to exceed two paragraphs, may be quoted without explicit permission provided that full credit, including $\odot$ notice, is given to the source. 
Real Effects of the Subprime Mortgage Crisis: Is it a Demand or a Finance Shock?

Hui Tong and Shang-Jin Wei

NBER Working Paper No. 14205

July 2008

JEL No. G1,G3

\begin{abstract}
$\underline{\text { ABSTRACT }}$
We develop a methodology to study whether and how a financial-sector crisis can spill over to the real economy, and apply it to the case of the ongoing subprime mortgage crisis. If there is a spillover, does it manifest itself primarily by reducing consumer confidence and consumer demand? Is there also a supply-side channel through a tightened liquidity constraint faced by non-financial firms? Since most firms appear to have much larger cash holdings than in the past, some suggest that a liquidity constraint is not likely to be a significant factor for non-financial firms. We propose a methodology to estimate the importance of these two channels for spillovers. We first propose an index of a firm's sensitivity to a shock to consumer confidence, based on its response to the $9 / 11$ shock in 2001 . We then construct a separate firm-level index on financial constraint based on Whited and Wu (2006). As a robustness check, we also construct an alternative sector-level index of a firm's intrinsic demand for external finance, based on the work of Rajan and Zingales (1998). We find robust evidence suggesting that both channels are at work, but that a tightened liquidity squeeze appears to be economically more important than reduced consumer confidence or spending in explaining cross-firm differences in stock price declines.
\end{abstract}

\author{
Hui Tong \\ International Monetary Fund \\ 700 19th Street N.W. \\ Washington, DC 20431 \\ hui.tong@imf.org \\ Shang-Jin Wei \\ Graduate School of Business \\ Columbia University \\ Uris Hall, Room 619 \\ 3022 Broadway \\ New York, NY 10027-6902 \\ and NBER \\ shang.jin.wei@columbia.edu
}


"The financial market crisis that erupted in August 2007 has developed into the largest financial shock since the Great Depression, inflicting heavy damage on markets and institutions at the core of the financial system."

International Monetary Fund, World Economic Outlook, April 2008

[George Soros] noted, the financial crisis is beginning to have serious effects on the real economy, adding: “The extent of that is not, in my opinion, yet fully recognised."

Reuters (New York), April 9, 2008

\section{Introduction}

The subprime crisis that began in August 2007 has been called the worst financial crisis since the Great Depression by George Soros, Joseph Stiglitz, the International Monetary Fund, and other commentators. ${ }^{1}$ Furthermore, Soros thinks that the crisis may be affecting the real economy, though the extent of the effect is not yet fully known. In this paper, we study how the subprime crisis may spill over from the financial sector to the real economy. If there is a spillover, does it manifest itself primarily by reducing consumer demand and consumer confidence? Is there also a supply-side channel through tightened liquidity constraints faced by non-financial firms? Understanding these channels should help the design of an appropriate policy response.

The view that the real economy may suffer from a credit crunch as a result of the subprime meltdown is far from self-evident. As Bates, Kahle, and Stulz (2007) carefully document, non-financial firms held an abundance of cash prior to the crisis. According to

\footnotetext{
${ }^{1}$ See http://www.thisismoney.co.uk/investing-and-markets/article.html?in_article_id=437212\&in_page_id $=3 \& \mathrm{ct}=5 ;$ http://economictimes.indiatimes.com/International_Business/Financial_crisis_worst_since_1930s/ articleshow/2881608.cms; http://www.guardian.co.uk/business/2008/apr/10/useconomy.subprimecrisis.
} 
them, "the net debt ratio (debt minus cash, divided by assets) exhibits a sharp secular decrease and most of this decrease in net debt is explained by the increase in cash holdings. The fall in net debt is so dramatic that average net debt for US firms is negative in 2004. In other words, on average, firms could have paid off their debt with their cash holdings.” Given the apparent secular downward trend in cash holdings, the net debt ratio was likely even further into negative territory by mid-2007, right before the start of the full-blown subprime crisis. This at least suggests the possibility of no serious liquidity tightening outside the financial sector. Probably out of this belief, Federal Reserve Chairman Ben S. Bernanke called strong corporate balance sheets "a bright spot in the darkening forecast" during his testimony at the U.S. Congress on monetary policy on February 27, 2008.

We nonetheless believe that not all non-financial firms are equally well placed to weather the subprime shock. Indeed, as Figure 1a shows, many non-financial firms have experienced a dramatic decline in stock prices since the subprime crisis broke out in August 2007. If the crisis represents a tightening of liquidity beyond financial institutions, the effect is likely to be more damaging to those firms that are relatively more liquidity constrained to start with. Exploring this variation across firms may give us an entry into ascertaining the extent to which the subprime trouble affects the real economy. Of course, a tightening of liquidity need not be the only channel through which the subprime crisis could damage the real economy. Demand for firms' output could be compressed through a loss of consumer confidence, and hence a reduction in current and future consumer spending.

In this paper, we do not study how the subprime mortgage difficulties developed into a financial sector crisis. Instead, we take it as given that there has been a financial sector crisis since August 2007, and that it was caused by more frequent than expected 
delinquencies in subprime mortgages. We focus instead on investigating whether and how the financial sector crisis may spill over to non-financial firms. One empirical challenge is the potential endogeneity of our main explanatory variables. If non-financial firms fare badly when financial firms are not doing well, one can easily imagine a reverse causality story. Alternatively, simultaneously deteriorating performance in financial institutions and nonfinancial firms could be caused by a common third factor. We develop a methodology to study the mechanisms of a possible spillover, with attention to the issue of endogeneity.

We distinguish the demand sensitivity channel from the financial constraint channel. We first propose a sector-level index on the sensitivity to demand shocks, based on stocks' response to the 9/11/2001 shock. [We exclude firms in the airline, insurance, and defense industries because they were directly affected by the $9 / 11$ attack.] We then construct a firmlevel index on the degree of financial constraint, following Whited and $\mathrm{Wu}$ (2006). We further use an index on the intrinsic dependence on external finance developed by Rajan and Zingales (1998) as a robustness check. It is important to note that financial constraint refers to difficulties in raising external finance of all kinds, not merely in borrowing from banks.

As control variables, we add beta, firm size, and book/market ratio from the FamaFrench (1992) three factor model, and the fourth factor of momentum suggested by Lakonishok, Shleifer, and Vishny (1994). These factors are often but not always statistically significant. However, our two key regressors: financial constraint and consumer demand sensitivity, are always statistically significant with a correct sign. Our interpretation is that during the subprime crisis period, our two variables may reflect aspects of firm risks that are not completely captured by the three-factor, or the four-factor, model. As an extension, we further control for exposure to exchange rates and commodity prices. 
To address the endogeneity issue, we make sure that our key regressors, the degree of a firm's liquidity constraint, and its sensitivity to demand shock, are pre-determined with respect to the full-fledged financial crisis. In other words, our thought experiment is this: If we classify non-financial firms into different baskets, based on their ex ante degree of liquidity constraint, and ex ante sensitivity to demand shocks, would this classification help us to forecast the ex post stock price performance of these firms? If there is forecasting ability associated with these classifiers, would it carry over beyond what can be explained by the Fama-French three factors and the momentum factor?

We find that the answer to each question is yes. An increase in liquidity constraint by one standard deviation is associated with an additional decline in the stock price of 12.4 percentage points during July 31, 2007 - March 31, 2008. In comparison, an increase in sensitivity to consumer confidence by one standard deviation is associated with a contraction in stock price of 3.4 percentage points during the same period. As far as explaining crossfirm differences in the decline in stock prices is concerned, the liquidity constraint appears to be a more important channel quantitatively than does a contraction in consumer demand.

As another way to gauge the quantitative importance of liquidity constraint and demand contraction, and to track their effects over time, we turn to a "portfolio approach.” Specifically, we classify each stock along two dimensions: whether a stock has a high or low degree of liquidity constraint (i.e., whether its Whited-Wu index value is above or below the median across the firms in the sample), and whether a stock's sensitivity to a consumer demand contraction is above or below the median. We then group all stocks into four equally-weighted portfolios: the $\mathrm{HH}$ portfolio is a set of equally weighted stocks that are highly liquidity constrained and highly sensitive to consumer demand 
contraction; the HL portfolio is a set of stocks that are highly liquidity constrained, but relatively insensitive to a change in consumer demand and confidence. The LH and LL portfolios are defined accordingly. We find that the $\mathrm{HH}$ portfolio clearly shows the largest decline in stock prices, whereas the LL portfolio shows the smallest. The difference between the HH and LL portfolios in terms of the percentage fall in stock price is approximately half of the unconditional fall in the stock price. Moreover, between the two, most of the initial cross-firm difference in the magnitude of the fall in stock prices appears to be related to the cross-firm difference in the degree of liquidity constraints.

As our empirical approach is relatively novel, our interpretation stands or falls with whether our measures of demand sensitivity and liquidity constraint are truly clean and valid. We start by verifying that our index based on firm-level stock price response to the $9 / 11$ terrorist attack reflects primarily a demand shock, rather than contamination by a heavy dose of liquidity shock. To be sure, the market interest rate went up in the first few days following September 11, 2001. However, the Federal Reserve took decisive action to inject liquidity into the market. The interest rate went back to a level very close to the pre-9/11 level within two weeks, indicating that the market regarded the Federal Reserve's action as adequate in restoring the liquidity needed in the economy. At the same time, both economic forecasts of US growth rates by the International Monetary Fund and commercial forecasters, and consumer confidence measured by the Michigan Consumer Sentiment Index took a sharp downturn immediately following the $9 / 11$ attack. The sharply more pessimistic view of the US economy lasted for at least six months. This suggests that the 9/11 shock, measured over a month's period after the terrorist attack, reflects mostly a negative shock to consumer confidence, with virtually no liquidity element. To bolster our interpretation, we also run a 
placebo regression of stock price declines during the first month after the 9/11 shock on the Whited-Wu measure of liquidity constraints (using the end-of-2000 values of firm characteristics to ensure that the variables are pre-determined). Cross-firm differences in liquidity constraints turn out to be unimportant in explaining cross-firm differences in stock price declines during this period. This further suggests that the 9/11 index is not likely to be heavily contaminated by a liquidity constraint element.

We now come to the validity of our key measure of firm-level liquidity constraint. As a robustness check, we replace the Whited-Wu index of liquidity constraint by an index of sector-level intrinsic dependence on external finance proposed by Rajan and Zingales (1998). This new index also has a negative and statistically significant coefficient: firms that are naturally more reliant on external finance suffer a greater fall in stock prices. As an extension, we can also combine the Whited-Wu index and the Rajan-Zingales index in the same regression as they measure somewhat different things. We find that even among firms located in external-finance dependent sectors (according to the Rajan-Zingales index), those that are relatively more liquidity constrained (according to the Whited-Wu index) experience a particularly big fall in stock prices.

To ensure that our key regressors really pick up something unique to the subprime crisis period, we conduct a placebo test for the period of May 30 - July 30, 2007. We verify by a search of an electronic news database that the subprime problem was not yet widely recognized as a crisis during this period. We regress a change in stock price on firm-level liquidity constraint (as measured by the Whited-Wu index) and firm-level sensitivity to demand shock (as measured by our 9/11 index). It turns out that neither index is statistically significantly different from zero during this period. This suggests that prior to the outburst of 
the crisis in August 2007, stock price movements were not systematically related to liquidity constraint or demand sensitivity (as forward-looking stock prices had already priced in any known liquidity and demand shocks as of then).

Since the subprime crisis broke out in August 2007, there have been other changes in the economic environment. The most prominent factors are a dramatic depreciation of the US dollar relative to the euro, the yen and other currencies, and a steady rise in the oil price and other commodity prices. If one believes in the validity of the Fama-French three-factor model, one could understand our exercise as asking whether an ex ante classification of firms in terms of their liquidity constraint and sensitivity of demand help to explain firms' subsequent change in stock prices beyond what can be explained by the three factor model. This is a well-defined exercise by itself. In a sense, exposures to currency and commodity price movement should have been captured by the three factors (plus momentum) already. Nonetheless, as an extension, we make an attempt to account for the role of exchange rate and commodity price movements in explaining stock price changes since August 2007.

As we don't have systematic information on a breakdown of a firm's revenue and cost by country and currency from any standard database, we have to develop an indirect approach to gauge a firm's exposure to these currency and commodity price movements. We follow a three-step procedure. First, using weekly information during 2004-2006, we estimate a firm's sensitivity to movement in major currencies and commodity prices using a regression framework. Second, we collect firm-level sensitivity coefficients to currency and commodity price movement from the previous regressions, and combine them with the actual movement in major exchange rates and commodity prices after August 2007 to form a measure of each firm's realized exposure to these factors. Third, we add the firm-level 
exposure to these factors as additional control variables in our main regressions. Reassuringly, both liquidity constraint and demand sensitivity continue to have negative and statistically significant coefficients. In fact, the size of the point estimates is hardly affected by the addition of the exposure to currency and commodity price movement. At the same time, we find that some of the exposures, especially the to the hike in energy prices, do have a statistically significant effect on the stock prices of many firms.

This slew of robustness checks reinforce our interpretation that both liquidity tightening and a loss of consumer confidence have negatively affected non-financial firms during the subprime crisis. Furthermore, in terms of relative stock price movement, a tighter liquidity constraint appears to be, quantitatively, a more significant channel.

This paper is linked to the literature on credit crunches (for example, Bernanke and Lown 1991; Borensztein, and Lee 2002; Dell’Ariccia, Detragiache, and Rajan 2008, among others). We differ from the earlier literature by considering demand sensitivity together with liquidity constraint. Our measures of liquidity constraint, especially the use of the WhitedWu index, are new. More notably, our measure of sensitivity to a demand shock is novel. This paper is also related to a small but growing literature on the origin and consequences of the subprime problem as a financial crisis, including recent work by Mian and Sufi (2008), Reinhart and Rogoff (2008), Dell’Ariccia, Igan and Laeven (2008), and Greenlaw, Hatzius, Kashyap, and Shin (2008). As of now, we have not come across a paper directly documenting and quantifying the mechanisms by which the subprime mortgage crisis spills over from the financial sector to the real economy. In this sense, this paper fills an important void. 
The paper proceeds as follows. Section 2 presents our key specification, construction of key variables, and sources of data. Section 3 discusses the main empirical results and a slew of robustness checks and extensions. Section 4 offers concluding remarks.

\section{Specification and Key Variables}

\section{$\underline{2.1 \text { Basic specification }}$}

Our basic empirical strategy is to check whether an ex ante classification of firms by their characteristics in terms of degree of liquidity constraint and sensitivity to a contraction of consumer demand shock prior to the subprime crisis help to predict the ex post magnitude of their stock price changes since August 2007. To be precise, our basic specification is given by the following equation:

\section{(1) Stockreturn $_{i t}=\alpha_{0}+\beta_{1}$ DemandSensitivity $_{i}+\beta_{2}$ FinancialConstraint $_{i, t-1}+\varepsilon_{i t}$}

Note that this is a purely cross-sectional regression, and the key regressors are predetermined (in 2006). As a basic robustness check, we also add the three factors from Fama and French (1992): firm size (log of assets), the ratio of the market to book values, and beta (the correlation of the firm's stock return with the overall market). In some specifications, we also add a fourth control variable: a momentum factor from Lakonishok, Shleifer and Vishy (1994). The expanded specification is: 


$$
\begin{aligned}
& \text { (2) Stockreturn }{ }_{i t}=\alpha_{0}+\beta_{1} \text { DemandSensitivity }_{i}+\beta_{2} \text { FinancialConstraint }_{i, t-1}+\gamma_{1} \text { Size }_{i, t}
\end{aligned}
$$

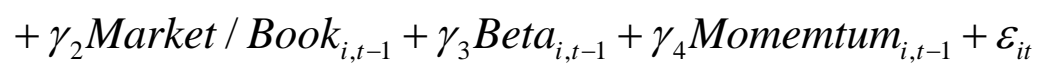

We follow Whited and Wu (2006) and incorporate the four factors by entering the relevant firm characteristics directly in our regressions rather than entering them indirectly by going through a factor model first. As control variables, these two ways of incorporating the four factors should be equivalent. Entering firm characteristics directly in our regressions is easier to implement, though the interpretation of the coefficients on these factors is a bit less straightforward.

While subprime loans were sporadically reported as problematic in late 2006 and early 2007, it began to be widely recognized as a crisis in August 2007. We conduct a search of news articles that contain the words "subprime" and "crisis" in all newspapers in the United States, excluding pricing and market data and republished news, and report the results in Figure 2. There was a clear spike in such news in early August 2007. The International Monetary Fund, as quoted at the beginning of the paper, also clearly thought of August 2007 as the starting date of a serious crisis. We therefore implement our main regressions for the period from early August 2007 - end of March 2008. We will also consider other sample periods as extensions or placebo tests.

\section{$\underline{2.2 \text { Key Data }}$}

\section{Percentage change in stock price}

The stock price data is from Datastream, with adjustments for dividends and capital actions such as stock splits and reverse splits. Figure 1a presents the stock price index for the S\&P 500 and its subcomponents over the period from January 2007 to March 2008. From 
there, we see that the cumulative decline of stock price index was approximately $14 \%$, with the largest drop coming from the financial sector. However, many non-financial firms also lost value, such as “consumer discretionary” firms.

Two key regressors are an index for sensitivity to consumer demand contraction and a measure of liquidity constraint. We discuss these in turn.

\section{Financial constraint index}

There is an active literature on measuring liquidity constraint. One popular measure is given by Kaplan and Zingales (1997). They use ex ante information to form judgments on which firms are liquidity constrained, and then use a regression framework to see which variables can best forecast whether a firm is liquidity constrained. This procedure leads them to define an index of liquidity constraint based on five variables: the ratio of cash flow to capital, Tobin's q, the ratio of debt to capital, the ratio of dividends to capital, and the ratio of cash to capital.

The most up-to-date and theoretically consistent measure is provided by Whited and Wu (2006). They cast liquidity constraints faced by a firm as the shadow value of cash (the value of a Lagrange multiplier in a firm's profit maximization problem). To be concrete, they derive their liquidity constraint in four steps. First, they write down a firm's dynamic optimization problem as to maximize the expected present discounted value of its future dividend stream, subject to two standard identity constraints (a definition of dividends, and a relationship between capital stock and investment) and two inequality constraints. The first inequality constraint is a lower bound on dividend payouts in a given period. A negative dividend is conceptually equivalent to a new share issuance "since on the margin the two 
have the same effect on old shareholders.” The lower bound is a measure of the firm's ability to raise external financing. The second inequality constraint is an upper bound on the stock of debt in a given period.

Second, they derive a set of first order conditions, including an Euler equation on capital stock and another Euler equation on stock of debt. To make the model appropriate for estimation, they replace the expectation sign with an expectational error term, and parameterize a cost of adjustment function for capital stock. Importantly, they specify a functional relationship between the Lagrange multiplier associated with the inequality constraint on a lower bound of dividend payout, which is the shadow value of raising external finance in a given period, and a set of nine variables that the existing literature has suggested to be relevant for liquidity constraint: (i) the ratio of cash flow to assets; (ii) a dummy that takes the value of one if the firm issues positive dividend in that period, and zero otherwise; (iii) the ratio of long term debt to total assets; (iv) the natural log of total assets; (v) the firm's three-digit industry sales growth; (vi) the firm's sales growth; (vii) the ratio of liquid assets to total assets; (viii) the number of analysts following the firm as reported by I/B/E/S; and (ix) the three-digit industry debt to assets ratio. The authors do not include a Tobin's q on this list because, citing results in Erickson and Whited (2000), they point out that “Tobin's q contains a great deal of measurement error in its role as a proxy for investment opportunities.”

Third, a Generalized Method of Moments (GMM) approach is used to estimate the parameters in the model. It turns out that the first six parameters in the equation on shadow value of external finance (which we will call the "financial constraint equation" thereafter) are statistically significantly different from zero at the ten percent level (according to a 
standard t-test) and the last three parameters are not significant. A joint significance test cannot reject the null hypothesis that the last three parameters are jointly equally to zero. Reassuringly, the signs of the first six coefficients are also consistent with economic theory and intuition. For example, the first parameter has a negative coefficient, implying that a reduction in the ratio of cash flow to total assets is associated with a tighter liquidity constraint for a firm (i.e. a higher shadow value of external finance).

Finally, Whited and Wu define their empirical measure of a firm's financial constraint as the fitted value of the liquidity constraint equation when only the six statistically significant variables are included.

In this paper, we use the coefficient estimates in Whited and Wu's preferred specification (i.e. Column 4 in Table 1 of their paper), and the values of the six constituent variables at the end of 2006, and define the fitted value of the financial constraint equation as an index for financial constraint. To be more precise, a firm's financial constraint index is given by the following equation:

\section{(3) Financial Constraint}

$$
\begin{aligned}
= & -0.091(\text { CashFlow / Asset })_{i t}-0.062 \text { DividendDummy }_{i t}+0.021(\text { Debt / Asset })_{i t} \\
& -0.044 \ln (\text { ASset })_{i t}+0.102 \text { IndustryGrowth }_{i t}-0.035 \text { FirmGrowth }_{i t}
\end{aligned}
$$

Firm-level balance sheet data come from Compustat USA. By construction, they are predetermined with respect to the onset of the subprime crisis.

Whited and Wu compare their index with another popular measure of financial constraint given by Kaplan and Zingales (1997). In simulated data, they find that the Kaplan- 
Zingales index does not perform well in selecting firms that are financially constrained by design. In a sense, this is not surprising as Whited and Wu could be regarded as a generalization of the Kaplan-Zingales index, but with a better grounding in the theory and in a more sound structural estimation from the data. As a result, we make the Whited-Wu index our primary measure of financial constraint.

As a robustness check, we also employ an alternative measure given by Rajan and Zingales (1998). The RZ index gives a sector-level approximation of a firm's intrinsic demand for external finance. Following Rajan and Zingales (1998), we define a firm's intrinsic demand for external financing by:

$$
\text { Dependence on external finance }=\frac{[\text { capital expenditures }- \text { cash flow }]}{\text { capital expenditures }} \text {, }
$$

where Cash flow $=$ cash flow from operations + decreases in inventories + decreases in receivables + increases in payables. All the numbers are based on US firms, which are judged to be least likely to suffer from financing constraints relative to firms in other countries. The original Rajan and Zingales (1998) paper covers only 40 (mainly SIC 2-digit) sectors. Here, we expand the number of sectors to around four hundred 4-digit SIC sectors. Our measure of intrinsic demand for external financing may be useful for other researchers as well.

To calculate the demand for external financing for US firms, we take the following steps. First, every firm is sorted into one of the 4-digit SIC sectors. Second, we calculate the ratio of dependence on external finance for each firm from 1990-2006. Third, we calculate the sector-level median from firm ratios for each SIC 4-digit sector that contains at least 5 firms, and the median value is then chosen, to be the index of demand for external financing in that sector. 
Conceptually, the Rajan-Zingales (RZ) index measures something related to but not identical to the Whited-Wu index. The RZ index aims to identify sector-level features, i.e. which sectors are naturally more dependent on external financing for their business operation. It ignores the question of which firms within a sector are more liquidity constrained. What the RZ index measures could be regarded as a "technical feature" of a sector, almost like a part of the production function. Of course, the RZ and WW indices should also be related: firms located in a sector that is naturally more dependent on external finance are also more likely to be liquidity constrained. Conversely, in a sector that does not need external finance, firms are less likely to be liquidity constrained. The simple correlation between the WW and RZ indices is 0.26 .

\section{Demand Sensitivity Index}

A second key regressor is an index of a firm's sensitivity to a contraction in consumer demand. There are no existing measures in the literature, so we have to invent one. Ideally, we want this index to reflect the sensitivity of a firm's stock price to a sudden, unexpected change in consumer confidence, or future consumer demand. We do not want the index to be contaminated by a firm's sensitivity to a liquidity shock or other factors.

We propose to construct such an index at the sector level based on the stock price reactions of the firms in that sector to the September 11, 2001 terrorist attack (from September 10, 2001 to September 28, 2001). The 9/11 shock can be argued to have been large and unexpected. We can verify that there was a big downward shift in consumer confidence and expected future consumption demand, as reflected by a downward adjustment in the forecast of subsequent US GDP growth, by the International Monetary Fund and other 
professional forecasters, in the aftermath of the shock. ${ }^{2}$ Figure 3 shows a sharp drop in consumer confidence right after Sept $11^{\text {th }}$, which stayed low for the subsequent four months. Figure 4 further shows that the consensus forecast for the 2002 US GDP growth rate also declined sharply by $1.5 \%$ after the $9-11$ shock, and stayed low for at least three months. The International Monetary Fund, in its special December 2001 issue of the World Economic Outlook, asserted that "the main impact [of the $9 / 11$ shock] is likely to depend primarily on the fall in demand generated by the loss in confidence about the economy". We therefore conclude the changes in stock price during September 10-28, 2001, capture firms' vulnerability to a loss in consumer confidence and an associated contraction in consumer demand.

At the same time, because the Federal Reserve took timely and decisive actions, it may be argued that the effect of the 9/11 shock on firms' financial constraint was small or at most short lived. In fact, the Federal Reserve announced on September 17, 2001: "The Federal Reserve will continue to supply unusually large volumes of liquidity to the financial markets, as needed, until more normal market functioning is restored." Figure 5 plots the spread between the three-month interest rate banks charge each other (in the euro-dollar market) over the three-month Treasury bills (TED spread) from early August to end of October in both 2001 and 2007. As we can see that, in the 2001 episode, both the level of real interest rate and the spread (risk premium), after an initial spike, quickly returned to a level that was only moderately higher than the pre-9/11 level. This suggests that the market likely regarded the Federal Reserve's actions in the first few days following the terrorist attack as

\footnotetext{
${ }^{2}$ The consensus forecast for the year of 2001 Real GDP growth rate dropped from $1.6 \%$ to $1 \%$, after the September 11 attack. Meanwhile, the consensus forecast for the year of 2002 dropped from $2.7 \%$ to $1.2 \%$.
} 
sufficient to restore the market's desired level of liquidity. Indeed, the International Monetary Fund, in its December 2001 supplemental issue of the World Economic Outlook, declared that "concerted policy responses by the US and other authorities to provide such liquidity were effective in quickly restoring market stability and heading off systemic concerns.” We therefore conclude that the cumulative stock price change over September 10-28, 2001, is unlikely to also reflect a firm's reaction to a deterioration of credit availability. [In contrast, the subprime crisis news is associated with a much greater increase in the TED spread.]

To construct the index, we first compute the change in log stock price for each US firm from September 10, 2001 to September 28, 2001. We then look at the mean of log stock price change for each four-digit SIC sector, and use it as the sector-level demand sensitivity. In this exercise, we drop the airlines, defense, and insurance sectors, which were affected directly by the terrorist attack. Excluding financial sector firms, we are left with 759 4-digit level sectors in total. We choose the three week window carefully. If the window is shorter than one week, the index may also reflect a firm's reaction to a perceived tightening of liquidity. If the window is longer than three months, the prospect for US GDP growth might be revised upward sufficiently by January 2002 that the index may not capture a firm's reaction to a perceived economic downturn.

\section{Other Variables and Summary Statistics}

In subsequent statistical analyses, we sometimes add other control variables, such as the three factors from the Fama-French (1992) and the momentum factor. The underlying data come from the CRSP database, including firm-level market beta. 
Table 1a reports summary statistics of the key variables. Demand sensitivity, liquidity constraint (the Whited-Wu index), and intrinsic dependence on external finance (the RajanZingales index) are all standardized to facilitate interpretation of subsequent regression coefficients. They all have a unitary standard deviation by construction. Table $1 \mathrm{~b}$ reports pair-wise correlations among the variables. It is particularly noteworthy that the correlation between the two key regressors, demand sensitivity and financial constraint, is as low as 0.01 . Hence they are virtually orthogonal to each other.

\section{Empirical Analysis}

\section{$\underline{3.1 \text { Basic Results }}$}

We examine percentage change in stock price (or more precisely, difference in log stock price) from July 31, 2007 to March 31, 2008 for US non-financial firms. In Column 1 of Table 2, we have the demand sensitivity index and the liquidity constraint (Whited-Wu) index as the only regressors. Both variables have a negative coefficient and are statistically significant: across firms, those that are more sensitive to a loss in consumer confidence, or were more liquidity constrained before the subprime crisis, experienced a greater fall in stock price during the subprime crisis. Since both variables are standardized, we can read off the point estimates directly: An increase in sensitivity to consumer confidence by one standard deviation is associated with an extra drop in stock price by 3.7 percent. In comparison, an increase in liquidity constraint by one standard deviation is associated with an extra drop in stock price by 11.7 percent. As far as variation across firms is concerned, liquidity constraint appears to be a quantitatively more important explanation than a loss of consumer confidence. 
[The relatively low R-squared does not overly bother us as this is a pure cross-sectional regression, and changes in stock prices are likely to be difficult to explain if the efficient market hypothesis is approximately correct.]

In Column 2 of Table 2, we add the three factors from the Fama-French model as controls. Two of the three factors are statistically significant. Firms with a high book to market ratio experience a greater decline in price. This is consistent with the idea that a higher such ratio represents a greater risk, and a riskier stock will exhibit a bigger price fall in bad times. [If we take the inverse of book/market ratio as a measure of investment opportunities, this means that firms with fewer investment opportunities lose more in stock value.] The firm size variable is not significant. This pattern is also present in the original Whited and Wu (2006) paper. According to their interpretation, liquidity constraint is the underlying reason why size matters for stock returns. Once we properly control for a theoryconsistent measure of liquidity constraint, firm size no longer matters. The coefficient on the "beta" variable is positive and significant. Somewhat surprisingly, it says that firms with a larger beta experience a smaller reduction in stock price, other things being equal. In any case, even with the three Fama-French factors controlled for, both demand sensitivity and financial constraint factors are still statistically significant. In Column 4, we add a momentum variable as an additional control. This variable is statistically significant. Stocks that have experienced a fall in price in the recent past are more likely to continue to fall in price in the subsequent periods. Again, controlling these four factors makes little difference to the statistical significance level or the size of the point estimates for demand sensitivity and liquidity constraint. Hence, our key conclusion appears robust: relatively more- 
constrained firms suffered a larger drop in stock price. The same is true for relatively more demand-sensitive firms.

If subprime problems disproportionately harm those non-financial firms that are more liquidity constrained and/or more sensitive to a consumer demand contraction, could financial investors earn excess returns by betting against these stocks (relative to other stocks)? This is essentially another way to gauge the quantitative importance of these two factors. We now turn to a "portfolio approach," and track the effects of the two factors over time. Specifically, we follow three steps. First, we classify each non-financial stock (other than airlines, defense and insurance firms) along two dimensions: whether its degree of liquidity constraint at the end of 2006 (per the value of the Whited-Wu index) is above or below the median in the sample, and whether its sensitivity to a consumer demand contraction is above or below the median. Second, we form four portfolios on July 31, 2007 and fix their compositions in the subsequent periods: the $\mathrm{HH}$ portfolio is a set of equally weighted stocks that are highly liquidity constrained and highly sensitive to consumer demand contraction; the HL portfolio is a set of stocks that are highly liquidity constrained, but relatively not sensitive to a change in consumer confidence; the LH portfolio consist of stocks that are relatively not liquidity constrained but highly sensitive to consumer confidence; and finally, the LL portfolio consists of stocks that are neither liquidity constrained nor sensitive to consumer confidence. Third, we track the cumulative returns of these four portfolios over time and plot the results in Figure 6.

Several interesting patterns can be discerned from the graph. First, the HH portfolio clearly has the largest cumulative decline in stock prices over time whereas the LL portfolio has the smallest. Second, the cumulative returns lines for the HH and HL portfolios are close 
to each other at the bottom of the group, whereas those for LL and LH are next to each other, on top of the group. This means, the quantitative effect of liquidity constraint (in explaining cross-firm difference in stock price declines) is much bigger than that of a loss in consumer confidence. Third, if one were to have formed a mega-portfolio at the beginning of August 2007, that shorted the HH portfolio and longed the LL portfolio, one would have earned a return on the order of 30 percent by the end of March 2008.

We cannot say that the quantitative effect of consumer confidence on the market as a whole is small because it could reduce the stock prices of all firms in a proportional fashion. However, the difference between the HH and LL portfolios in terms of the percentage fall in stock price is approximately half of the unconditional fall in the overall stock price (about 20 percentage points out of 40 percentage points from early August 2007 to end of March 2008). A conservative estimate is that at least half of the overall price decline is due to a tightening liquidity constraint (for those stocks that were liquidity constrained to start with).

\subsection{Evolving Roles of Liquidity Constraints and Demand Contraction}

Our primary regressions reported in Table 2 are conducted on the sample period from July 31, 2007 to March 31, 2008. They look into the roles of liquidity constraint and consumer confidence in explaining the cumulative stock price decline during the period. As an alternative, we can trace the roles of these two factors over time by conducting the same regressions over a set of gradually expanding sample periods, adding one month each time to the sample, but always controlling for size, book/market ratio, beta, and momentum. Specifically, we perform the first regression on the period from July 31, 2007 to August 31, 2007, the second regression from July 31, 2007 to September 30, 2007, and so on, until the 
eighth regression from July 31, 2007 to March 31, 2008. The specification is always the same as in Column 3 of Table 2. A major difference between this exercise and the analysis of the four portfolios discussed above is the control for the three Fama-French factors and momentum. Instead of reporting the detailed results of the eight regressions, we summarize the coefficients on the two key regressors, liquidity constraint and demand sensitivity, in Figure 7. While the point estimates (and the corresponding standard errors in parenthesis) for demand sensitivity are 0.33 (0.23), -0.01 (0.34), -0.12 (0.45), -0.38 (0.57), -0.61 (0.65), -2.03 (0.65), -2.65 (0.73), and -2.72 (0.80) respectively; the point estimates for financial constraint are -1.98 (0.62), -0.07 (0.91), -1.22 (1.23), -2.84 (1.54), -4.84 (1.75), -7.55 (1.76), -8.26 (1.98), and -12.50 (2.18), respectively.

Several features of the data are worth noting. First, in the first month of the sample (July 31, 2007 - August 31, 2007), the coefficient on liquidity constraint is negative, but the coefficient on sensitivity to consumer confidence is zero. By searching news reports, we find that this was the time when the subprime woes were first thought of as a widespread crisis. American Home Mortgage filed for bankruptcy on August 6. The news broke on August 16 that Countrywide Financial Corporation had to take out an emergency loan of \$11 billion to narrowly escape bankruptcy. Financial institutions outside the United States such as BNP Paribas started to reveal large exposure to US subprime losses. A major presidential candidate, Hillary Clinton, proposed a bailout fund for homeowners at risk of foreclosure on August 7. Perhaps more significantly, the Federal Reserve Board lowered the discount rate by 50 basis points to 6.25 percent, while President Bush announced a limited bailout of homeowners on August 31, 2007. However, there was only a very modest adjustment in the consensus forecast of US GDP growth rate in that month (see Figure 2a). Apparently, while 
the subprime woes were recognized as a shock to the financial system, it was not widely expected then that they would have a major negative impact on the US economy.

Curiously, during the second sample period (July 31, 2007 - September 31, 2007) neither coefficient is different from zero. It is possible that market participants interpreted the actions taken by the Federal Reserve and the President as being sufficient to prevent a spillover of the crisis from the financial sector to the real economy given what market participants thought they knew about the extent of the subprime problem. However, bad news did not stop coming in August. The British bank Northern Rock experienced a bank run in mid-September. Former Federal Reserve Chairman Alan Greenspan joined the fray by declaring that the fall of housing prices was likely going to be "larger than most people expect." More and more financial institutions started to reveal bad news about exposure to subprime loan products in September, November, and the first quarter of 2008. The Federal Reserve took a succession of actions including lowering policy interest rates and expanding liquidity provisions over this period. The Federal Government also took several initiatives (for example, the creation of the Hope Now Alliance, the announcement to encourage a voluntary and temporary freeze of mortgage payments, and the attempt to modernize the Federal Housing Authority). At the same time, the market began to reassess the seriousness of the subprime problem and its impact on the real economy. In Figure 7, the market reaction to these developments manifests itself in incrementally more negative coefficients on the key regressors over time. This is shown most clearly in the case of liquidity constraint. The coefficient became -1.2 in October and increased in absolute value steadily month by month, until reaching -12.5 by the end of March 2008. In relative terms, a loss of consumer confidence was not perceived to be a major factor until December 2007. Even then, the 
coefficient on sensitivity to consumer confidence was always smaller than that on liquidity constraint in every subsequent sample period, reaching -2.72 by the end of March 2008 .

A deterioration of financial constraint faced by non-financial firms in the first quarter of 2008 is consistent with a Senior Loan Officer Survey conducted in April 2008. ${ }^{3}$ About $55 \%$ of domestic US banks, up from about $30 \%$ in the January survey, reported to have tightened lending standards on loans to large and medium-sized (non-financial) firms over the preceding three months. Moreover, about $70 \%$ of the banks—up from about $45 \%$ in the January survey—indicated that they had increased the spread of loan rates over their cost of funds. They noted that concerns about their current or expected capital positions had contributed to more stringent lending policies over the preceding three months.

To summarize, the realization that liquidity constraints and a contraction of consumer demand could damage the real economy outside the financial sector looks like a gradually unfolding drama. Throughout the sample period, tightening liquidity constraints are a leading actor, always perceived to be more important, while the loss in consumer confidence is a supporting actor, playing a quantitatively smaller role in explaining cross-firm differences in stock performance.

\subsection{Alternative Measure of Financial Dependence}

For our story to be persuasive, we have to make sure that the key measure of liquidity constraint is valid and informative. We therefore conduct several additional checks. The Whited-Wu index has been used as a measure of liquidity constraint at the firm level in all

\footnotetext{
${ }^{3}$ http://www.federalreserve.gov/boarddocs/snloansurvey/200805/
} 
the regressions so far. As an alternative, we follow Rajan and Zingales (1998) and adopt a sector-level measure of a firm's intrinsic demand for external finance. As noted in the data section, the underlying idea behind Rajan and Zingales (1998) is different from Whited-Wu (2006); the simple correlation between the Rajan-Zingales (RZ) index and the Whited-Wu (WW) index is 0.26 . This means that the RZ index can potentially provide an informative and independent check on the notion that financial constraint plays a major role in explaining the effect of the subprime crisis on non-financial firms. While the original RZ index was constructed for 40-some sectors at the SIC 2-digit level, we expand it to cover about 400 sectors at the SIC-4-digit level (following the same conceptual framework).

In Column 1 of Table 3, we report the regression in which the WW index is replaced by the RZ index. As we can see, both the RZ index and the demand sensitivity index have negative coefficients that are statistically significant at the $1 \%$ level. In particular, those firms that naturally rely more on external finance for business operation experience a bigger fall in stock prices during the subprime crisis period. An increase in the RZ index by one standard deviation is associated with a bigger decline in stock price, by 3 percentage points.

Because the RZ and the WW indices measure somewhat different aspects of a firm's dependence on external finance, we can also include both in a regression and also explore the role of their interaction. This is done in Column 2 of Table 3. It turns out that the Whited-Wu index, the Rajan-Zingales index, and an interaction term between the two all produce negative coefficients that are significant at least at the $5 \%$ level. In other words, firms that were liquidity constrained at the beginning of the sample period fared worse in their stock prices following the outbreak of the subprime crisis. This effect is magnified for firms that 
were both liquidity constrained and located in sectors that are naturally more dependent on external finance.

In Columns 3 and 4 of Table 3, we add the Fama-French three factors (firm size, book/market ratio, and beta) and the momentum factors, respectively, to the above regression. Clearly, even after controlling for these four factors, liquidity constraint, intrinsic dependence on external finance, and their interactions (as well as sensitivity to demand shock) continue to have negative coefficients that are significant at the $1 \%$ level. This provides some additional support for our contention that there was a real financial shock that negatively impacted non-financial firms in a statistically and economically significant way during August 2007 - March 2008.

\section{$\underline{3.4 \text { Placebo Tests }}$}

We use firm-level stock price reaction to the September 11, 2001 terrorist attack (the change in log stock price from September 10-September 30, 2001) as a measure of a firm’s sensitivity to a loss of consumer confidence/contraction of consumer demand in the subsequent subprime period. We supported the notion that there was an expectation of recession after the attack by providing evidence of a sharply more pessimistic forecast of US GDP growth by the International Monetary Fund and by professional commercial forecasters subsequent to the 9/11 shock that lasted well beyond September 30, 2001. Since the 9/11 attack directly and physically affected many financial institutions in the Wall Street, and the New York Stock Exchange was even closed for a few days, it is reasonable to ask whether our 9/11 index could also partly reflect a firm’s sensitivity to a tightening liquidity constraint. If it is, then this could contaminate our interpretation of the results reported in Table 2. We 
previously argued in the data section that any effect on cost of capital and availability of external finance from the 9/11 attack was temporary and short-lived (as shown in Figure 3). By the choice of our time window (September 10-30, 2001), the 9/11 index (or the variation across firms in stock price responses) is not likely to be severely contaminated by firms' sensitivity to financial constraint.

We now perform a placebo test that examines this directly. Specifically, we measure a firm's degree of liquidity constraint by the Whited-Wu index, using the values of the constituent variables at the end of 2000. [This is exactly parallel to the measure of liquidity constraint during the subprime period reported in Table 2, where the constituent variables of the Whited-Wu index are based on their end-of-2006 values.] We ask whether this direct measure of liquidity constraint helps to explain the magnitude of stock price declines during September 10, 2001-September 30, 2001, the period we use to construct the index for demand sensitivity. The results are presented in Table 4. We find that financial constraint is not statistically significant: Varying degrees of liquidity constraint across firms (in 2000) do not explain cross firm differences in stock price reactions after the 9/11 shock. This increases our confidence that the $9 / 11$ index is not likely to be contaminated by firm's sensitivity to liquidity constraint itself.

Our principal claim is that the subprime crisis affects the real sectors in the economy through a combination of a tightening liquidity constraint and a contraction of consumer demand. How do we know these two factors only became important after the subprime trouble began to be recognized as a large-scale crisis in August, 2007?

We now conduct a different placebo test, replicating the key regressions in Table 2, but on a sample period prior to the subprime trouble being recognized as a generalized crisis. 
Table 5 reports these regressions for the period June 30 to July 31, 2007 (firm-level financial constraints are still measured based on end-2006 values of the Whited-Wu index). Neither financial constraint nor demand sensitivity is statistically significant. A lack of statistical significance on the Whited-Wu index suggests that it was not a general predictor of future firm value before August 2007. A lack of statistical significance on the demand sensitivity variable confirms the information in Figures 2a and 2b: As there was no general expectation of a demand contraction, there was no reason as yet then for stocks that were more sensitive to a demand contraction to do worse than other stocks. This also reinforces our confidence that the 9/11 index appears to capture firms' sensitivity to a change in consumer demand. We replicate the same exercise for an earlier period (January 1, 2007 - May 30, 2007), and find the same pattern (of no statistical significance for demand sensitivity or liquidity constraints). This leads us to conclude that the data patterns in Table 2 are really those associated with the subprime crisis period, and not with other factors present in earlier periods.

\section{$\underline{3.5 \text { Exposures to Exchange Rate and Commodity Price Movements }}$}

Since the subprime crisis broke out in August 2007, there have been other developments in the economy that could affect stock prices ex post. Most prominently, the US dollar depreciated against the euro and the Japanese yen by 15 and 18 percent, respectively, during July 31, 2007 - March 31, 2008; the world oil price increased by close to 40 percent during the same period. The dollar depreciation would presumably increase the profit of export-oriented firms but reduce that of those that rely heavily on imported inputs. Similarly, the energy price hike would likely increase the profit of energy producers but reduce that of most other companies. 
Recall that both our liquidity constraint and demand sensitivity variables are measured using data collected prior to the subprime crisis period (i.e. based on information available in 2006 and 2001, respectively). Since we are interested in understanding whether an ex ante classification of firms by their degree of liquidity constraint and sensitivity to demand contraction could help predict their ex post stock price movement during the subprime crisis period, we may argue that the Fama-French three factors plus the momentum factor have already summarized all the other ex ante information relevant for stock returns. In other words, the specifications in Tables 2 and 3 are already sufficient; there is no need to incorporate ex post firm exposures to exchange rate and commodity price movements as additional controls.

Nonetheless, there could be coincidental correlations between our ex ante measure of liquidity constraint (or demand sensitivity) and the ex post realized movement in exchange rates and commodity prices. As a robustness check, we now attempt to control for a firm's exposures to currency and commodity price movement. An immediate difficulty that we face is a lack of systematic information on firm revenue and cost by currency, or on a firm's exposure to commodity price movement. We follow Adler and Dumas (1984) and Dominguez and Tesar (2001 and 2006) by constructing our own indices for exposure to exchange rates and commodity prices. Specifically, we follow a three-step procedure. In Step 1, we measure the relationship between weekly stock prices and major exchange rates and commodity prices in the three calendar years prior to the subprime crisis. More precisely, for each firm, we regress its weekly stock returns on the S\&P 500 market return, percentage changes in the euro-dollar exchange rate and the yen-dollar exchange rate, and percentage changes in three commodity groups' spot price indices (energy, agricultural products, and 
metals) during the period from 2004 to $2006 .{ }^{4}$ We collect the five estimated coefficients on the exchange rates and the commodity prices for each firm. In step 2, we multiply these coefficients individually with the realized percentage changes for these exchange rates and commodity price indices over July 31, 2007 - March 30, 2008. ${ }^{5}$ These are firm-level ex post exposures to major currencies and commodity prices. In step 3, we add these five exposure variables as additional controls in our main regressions. Note that in the first step, an oil producer would likely have a positive coefficient on the energy price index, whereas a firm that uses oil as an input would likely to have a negative coefficient. As a result, all exposure variables are expected to enter Step 3 with a positive sign.

We report the regression result (Step 3 above) in the first column of Table 6. Of the five new control variables, the coefficient on energy price exposure is positive and statistically significant: energy producers, relative to energy users, experienced a much smaller drop in stock prices (or maybe even experienced an increase in stock prices) during July 31, 2007 - March 31, 2008. The coefficients on the two exchange rates and the agriculture price exposure are not different from zero statistically. This could mean that most firms in the sample did not have much exposure to these factors. Alternatively, it could mean that most firms had already undertaken adequate hedging strategies, including buying currency futures and options, so that ex post realized movements in exchange rates and agricultural prices did not have a material impact on their profit. The coefficient on metal price exposure has a negative sign. We do not have a good explanation except to note that

\footnotetext{
${ }^{4}$ For more details on the S\&P commodity spot price indices, see http://www2.goldmansachs.com/services/ securities/products/ sp-gsci-commodity-index/tables.html.

${ }^{5}$ From July 31, 07 to March 31, 08, the price of agriculture and energy rose by $36 \%$ and $29 \%$ respectively, while the price of metal declined by $0.7 \%$.
} 
this turns out not to be robust in subsequent specifications (reported in the last two columns of Table 6).

We now come to our two key regressors: liquidity constraint and demand sensitivity. Both continue to have a negative coefficient that is statistically significant at the 1 percent level. In fact, the size of the point estimates is virtually unaffected by the inclusion of the exposures to major exchange rates and commodity prices.

In Column 2 of Table 6, we add the Rajan-Zingales measure of intrinsic dependence on external finance, and its interaction with the Whited-Wu measure of liquidity constraint. As in Table 3, liquidity constrained firms experienced a bigger fall in stock prices during the subprime crisis period, especially for those located in sectors that are naturally more reliant on external finance.

In constructing our firm-level exposures to major exchange rates and commodity prices, we notice that some of the coefficients in firm-by-firm regressions (in Step 1 discussed above) are not different from zero statistically. As an alternative way to construct our exposure variables, we assign these coefficients to be zero and redo our regressions. The regressions with the alternative definition of the exposures are reported in Columns 3 and 4 of Table 6. The coefficient on the energy exposure variable is still positive and significant, with the point estimate 20 percent larger than before. The two exchange rate exposures are still insignificant. This time, the metal price exposure becomes insignificant but the agriculture price exposure becomes negative and significant. Other than these, there are no material changes to the regression results. In particular, firms that are more liquidity constrained or more sensitive to demand contraction continue to exhibit a larger decline in their stock prices during the subprime crisis period. 
As an extension, we have also attempted to control for firm-level exposure to interest rate changes. It is possible that different firms may respond differently to a given rise in the interest rate, for reasons unrelated to their liquidity constraints. We account for this using a methodology similar to the approach to control for a firm's exposure to exchange rates and commodity prices. Specifically, we first estimate a firm-level sensitivity to these factors by regressing weekly stock returns on the market return, changes in the two exchange rates, changes in the three commodity price indices, and then changes in the interest rate (proxied by 3-month Treasury bills) during the period from $2004-2006$. Using the estimated coefficients and the actual realized change in the interest rate during July 31, 2007 - March 30, 2008, we can compute a firm-specific exposure to interest rate change (and similarly, exposures to changes in exchange rates and commodity prices). Incorporating the interest rate exposure in specifications like those in Table 6 reveals no material effect on the estimates or the significance levels of the coefficients on either the demand elasticity or the liquidity constraint variable (regression results not reported to save space).

\subsection{Additional Robustness Checks and Extensions}

We construct an alternative index of sensitivity to a demand shock that purges the influence of the four factors: firm size, book/market, beta, and momentum. In other words, we first regress change in log stock prices during September 10-28, 2001 on the four factors (which is reported in the first column of Table 4). We then use the residual to construct an alternative index of a firm's sensitivity to demand shocks. We redo all the regressions in Tables 2 and 3 but find the results to be virtually unaffected. To be precise, the coefficients on demand sensitivity and financial constraint are negative and statistically significant at the 
1 percent level. The point estimates are slightly smaller than, but not statistically different from, those in Tables 2 and 3.

The demand sensitivity index is measured at the 4-digit sector level so far. We also construct the index at the three and two-digit SIC levels as a robustness check. The threedigit level index is constructed as the mean of the index at the four-digit level, and the twodigit level index as the mean of the index at the three-digit level. Because different three (two) digit sectors have uneven number of four (three) digit sectors, these alternative constructions also effectively reassign weights to the firms. We re-run all regressions in Table 2 and find similar results. For example, when using the three-digit level index for the specification in the last column of Table 2, the estimated coefficient on demand sensitivity is -2.21 , with a standard error of 0.84. In other words, the point estimate is a bit smaller, but still significant at the 1 percent level.

We note in the introduction that many firms had larger cash holdings in recent years than in the past. Some may point to this and argue that a liquidity constraint is not likely to be a significant factor during the current subprime crisis. However, the level of cash holding is in principle endogenous. For example, it could be a response to increased risk associated with more volatile cash flows (as pointed out by Bates, Kahle, and Stulz 2007). We add a firm’s “cash and short-term investments" as an additional control to a specification otherwise identical to Column 3 of Table 2. The associated coefficient turns out to be negative and statistically significant at the 1 percent level, with a point estimate of -12.8 , and a standard error of 3.90. In other words, those firms with a higher cash stock actually experienced a larger drop in stock prices. This is consistent with the view that a higher level of cash holding is a sign of a riskier cash flow: when a crisis hits, these firms are likely to fare worse. 
Reassuringly, the coefficients on both liquidity constraint and demand sensitivity continue to be negative and statistically significant at the 1 percent level. In fact, the point estimates are very close to those in Table 2.

\section{Conclusion}

In this paper, we propose a methodological framework to study the underlying mechanisms by which a financial-sector crisis may affect the real sector, and apply it to the case of the subprime mortgage crisis. In particular, we are interested in documenting and quantifying the importance of tightening liquidity constraints and the deterioration of consumer confidence on non-financial firms. We ask the question: could an ex ante classification of the firms based on their degrees of liquidity constraint and sensitivity to demand contraction prior to the subprime crisis help to predict their ex post stock price performance during the crisis period? We find the answer to be a resounding yes. Both channels are at work; liquidity constraints appear to be more significant quantitatively in explaining cross firm differences in the magnitude of stock price declines. A conservative estimate is that a tightening liquidity constraint is likely to explain at least half of the actual drop in stock prices for firms that were liquidity constrained to start with.

In order to reach these conclusions, we propose a novel methodology that distinguishes a shock to the supply of finance from an expected contraction of economic demand. We measure a firm's sensitivity to demand contraction by its stock price reaction to the September 11, 2001 terrorist attack (change in log stock price from September 10, 2001 to September 30, 2001). We measure a firm's liquidity constraint by the Whited-Wu (2006) 
index, valued at the end of 2006. We conduct extensive robustness checks to ensure that these indicators are valid and informative. For example, we verify that the 9/11 index is not contaminated by the impact of a liquidity constraint itself. While liquidity constraint and demand sensitivity, as measured by these two indicators, have statistically significant power in predicting stock price movement during the subprime crisis period, placebo tests suggest that they do not predict stock price movement in a period shortly before the subprime crisis broke out. An alternative measure of a firm's dependence on external finance proposed by Rajan and Zingales (1998) and valued based on information during 1990 - 2006 also has predictive power about stock price movement during the subprime crisis period.

Correctly diagnosing the transmission channels for a financial crisis to affect the real economy has implications for designing appropriate policy responses to the crisis. For the subprime mortgage crisis, our analysis suggests that policies that aim primarily at restoring consumer confidence and increasing demand, such as a tax rebate to households, will probably be insufficient to help the real economy; policies that could relax liquidity constraints faced by non-financial firms are likely to be indispensable. Our methodology should also be useful in other contexts where effects of a financial shock to the real economy need to be measured. We leave these applications for future work. 


\section{References:}

Adler, Michael, and Bernard Dumas, 1984, “Exposure to Currency Risk: Definition and Measurement,” Financial Management, 13: 41-50, Summer.

Bates, Thomas W., Kathleen M. Kahle, and René M. Stulz, 2007, "Why do U.S. firms hold so much more cash than they used to?” Ohio State University Working paper.

Bernanke, Ben S, 2008, Semiannual Monetary Policy Report to the Congress, February 27, 2008. http://www.federalreserve.gov/newsevents/testimony/bernanke20080227a.htm

Bernanke, Ben S., and Cara S. Lown, 1991, “The Credit Crunch,” Brookings Papers on Economic Activity, No.2: 205-247.

Borensztein, Eduardo, and Jong-Wha Lee, 2002, "Financial Crisis and Credit Crunch in Korea: Evidence from Firm-level Data,” Journal of Monetary Economics, 49: 853-875.

Dell’Ariccia, Giovanni, Enrica Detragiache, and Raghuram Rajan, 2008, “The Real Effect of Banking Crises,” Journal of Financial Intermediation, 17: 89-112.

Dominguez, Kathryn, and Linda L. Tesar, 2001, "A Reexamination of Exchange Rate Exposure," American Economic Review 91(2): 396-399, May issue.

Dominguez, Kathryn, and Linda L. Tesar, 2006, "Exchange Rate Exposure," Journal of International Economics 68: 188-218.

Erickson, T., and T. M. Whited, 2000, “Measurement Error and the Relationship Between Investment and q,'” Journal of Political Economy, 108, 1027-1057.

Fama, Eugene F., and Kenneth R. French, 1992, “The Cross-Section of Expected Stock Returns,” Journal of Finance 47, 427-465.

Fazzari, S., R. G. Hubbard, and B. C. Petersen, 1988, “Financing Constraints and Corporate Investment,’’ Brookings Papers on Economic Activity, 1, 141-195.

Greenlaw, David, Jan Hatzius, Anil K Kashyap, Hyun Song Shin, 2008, “Leveraged Losses: Lessons from the Mortgage Market Meltdown,” draft paper prepared for US Monetary Policy Forum Conference.

Henriques, Diana B (2008), “Unlike Consumers, Companies Are Piling Up Cash”, New York Times, March 4, 2008.

Kaplan, S., and L. Zingales, 1997, “'Do Financing Constraints Explain Why Investment is Correlated with Cash Flow?’’ Quarterly Journal of Economics, 112, 169-216. 
Lamont, O., C. Polk, and J. Saa-Requejo, 2001, “Financial Constraints and Stock Returns,” Review of Financial Studies, 14, 529-544.

Lakonishok, J., Shleifer, A. \& Vishny, R.W. 1994, "Contrarian investment, extrapolation and risk," Journal of Finance, vol. 49, pp. 1541-78.

Mian, Atif, and Amir Sufi, 2008, “The Consequences of Mortgage Credit Expansion:

Evidence from the 2007 Mortgage Default Crisis,” University of Chicago Graduate School of Business Working Paper.

Rajan, Raghuram and Luigi Zingales, 1998, "Financial dependence and growth,” American Economic Review 88: 559-586.

Reinhart, Carmen, and Kenneth Rogoff, 2008, "Is the 2007 U.S. Sub-Prime Financial Crisis So Different? An International Historical Comparison,” University of Maryland and Harvard University working paper.

Whited, Toni, and Guojun Wu, 2006, "Financial Constraints Risk," Review of Financial Studies 19 (2006): 531-559. 
Table 1a: Summary Statistics

\begin{tabular}{|c|c|c|c|c|c|c|}
\hline Variable & \# Obs & Median & Mean & St Div & Min & Max \\
\hline $\begin{array}{l}\text { Percentage Change in Stock Price } \\
\text { (July 31, } 2007 \text { - March 31, 2008) }\end{array}$ & 2760 & -22.2 & -30.1 & 44.7 & -180.7 & 48.6 \\
\hline $\begin{array}{l}\text { Demand Sensitivity } \\
\text { (Reaction to the 9-11 news) }\end{array}$ & 2789 & 1.42 & 1.56 & 1.00 & -0.83 & 4.10 \\
\hline $\begin{array}{l}\text { Financial Constraint } \\
\text { (Whited-Wu index) }\end{array}$ & 2789 & -2.31 & -2.24 & 1.00 & -4.19 & 0.21 \\
\hline $\begin{array}{l}\text { External Finance Dependence } \\
\text { (Rajan-Zingales index) }\end{array}$ & 2687 & 0.17 & 0.54 & 1.00 & -0.39 & 3.55 \\
\hline Constraint (WW)*Dependence (RZ) & 2687 & -0.35 & -0.96 & 2.11 & -14.88 & 1.63 \\
\hline Firm Size (log assets) & 2789 & 5.81 & 5.77 & 2.16 & -1.89 & 13.45 \\
\hline Book/Market Ratio & 2722 & 0.76 & 1.20 & 2.54 & 0.01 & 76.5 \\
\hline Beta & 2495 & 1.03 & 1.08 & 0.74 & -2.54 & 4.27 \\
\hline Momentum & 2506 & 4.54 & 2.58 & 30.88 & -162.09 & 306.95 \\
\hline
\end{tabular}

\section{Table 1b: Correlation among Variables}

\begin{tabular}{lcccccccc}
\hline & Stock & $\begin{array}{c}\text { Demand } \\
\text { return }\end{array}$ & $\begin{array}{c}\text { Sensitivity } \\
\text { Constraint }\end{array}$ & $\begin{array}{c}\text { External } \\
\text { Finance }\end{array}$ & $\begin{array}{c}\text { WW* } \\
\text { RZ }\end{array}$ & $\begin{array}{c}\text { Firm } \\
\text { Size }\end{array}$ & $\begin{array}{c}\text { Book/ } \\
\text { Market }\end{array}$ & Beta \\
Demand Sensitivity & -0.07 & & & & & & & \\
Financial Constraint-WW & -0.26 & 0.01 & & & & & & \\
External Finance Dependence (RZ) & -0.07 & -0.09 & 0.26 & & & & & \\
Constraint (WW)*Dependence (RZ) & -0.02 & 0.07 & 0.02 & -0.85 & & & & \\
Firm Size & 0.22 & 0.00 & -0.92 & -0.21 & -0.02 & & & \\
Book/Market & -0.15 & 0.05 & -0.11 & -0.15 & 0.11 & 0.17 & & \\
Beta & 0.11 & 0.09 & -0.27 & -0.04 & 0.01 & 0.30 & -0.05 & \\
Momentum & 0.17 & 0.03 & -0.10 & -0.12 & 0.08 & 0.07 & 0.03 & 0.03 \\
\hline
\end{tabular}




\begin{tabular}{lccc}
\hline \multicolumn{4}{c}{ Table 2. Change in Stock Price during the Subprime Crisis } \\
& 1 & 2 & \\
(July 31, 2007-March 31, 2008) & 3 \\
Demand Sensitivity & $-3.69^{* * *}$ & $-3.27^{* * *}$ & $-3.37^{* * *}$ \\
& {$[0.85]$} & {$[0.88]$} & {$[0.87]$} \\
Financial Constraint-WW & $-11.67^{* * *}$ & $-13.72^{* * *}$ & $-12.35^{* * *}$ \\
& {$[0.82]$} & {$[2.33]$} & {$[2.32]$} \\
Firm Size & & -0.31 & 0.10 \\
& & {$[1.15]$} & {$[1.14]$} \\
Book/Market Ratio & & $-6.24 * * *$ & $-6.37^{* * *}$ \\
& & {$[0.64]$} & {$[0.63]$} \\
Beta & & $3.13^{* *}$ & $3.01^{* *}$ \\
& & {$[1.25]$} & {$[1.24]$} \\
Momentum & & & $0.20^{* * *}$ \\
Constant & & & {$[0.03]$} \\
& & & $-51.93^{* * *}$ \\
Observations & $2.35 * * *$ & $-52.75^{* * *}$ & {$[3.10]$} \\
R-squared & 0.07 & {$[3.13]$} & 2410 \\
\hline
\end{tabular}

Notes: Standard errors in brackets; ***, **, and * denote p-value less than $1 \%, 5 \%$, and $10 \%$, respectively. Stock return, financial constraint, and demand sensitivity are winsorized at the $2 \%$ level. 
Table 3: Alternative Measure of Financial Dependence

LHS variable $=$ Change in Stock Price during the Subprime Crisis 7/31/07-3/31/08

\begin{tabular}{|c|c|c|c|c|}
\hline & 1 & 2 & 3 & 4 \\
\hline Demand Sensitivity & $\begin{array}{c}-4.00 * * * \\
{[0.92]}\end{array}$ & $\begin{array}{c}-3.87 * * * \\
{[0.89]}\end{array}$ & $\begin{array}{c}-3.30 * * * \\
{[0.91]}\end{array}$ & $\begin{array}{c}-3.41^{* * *} \\
{[0.90]}\end{array}$ \\
\hline $\begin{array}{l}\text { External Finance Dependence } \\
\text { (RZ index, based on 90-06) }\end{array}$ & $\begin{array}{c}-3.03 * * * \\
{[0.90]}\end{array}$ & $\begin{array}{l}-3.18^{*} \\
{[1.84]}\end{array}$ & $\begin{array}{c}-6.55 * * * \\
{[2.02]}\end{array}$ & $\begin{array}{c}-5.74 * * * \\
{[2.00]}\end{array}$ \\
\hline $\begin{array}{l}\text { Financial Constraint } \\
\qquad \text { (WW index, } 2006 \text { value) }\end{array}$ & & $\begin{array}{c}-10.94^{* * *} \\
{[0.98]}\end{array}$ & $\begin{array}{c}-11.81^{* * *} \\
{[2.53]}\end{array}$ & $\begin{array}{c}-10.81 * * * \\
{[2.51]}\end{array}$ \\
\hline Financial Constraint & & $-1.60 * *$ & $-2.66 * * *$ & $-2.56 * * *$ \\
\hline *External Finance Dependence & & {$[0.81]$} & {$[0.86]$} & {$[0.85]$} \\
\hline Firm Size & & & $\begin{array}{c}-0.17 \\
{[1.18]}\end{array}$ & $\begin{array}{c}0.15 \\
{[1.17]}\end{array}$ \\
\hline Book/Market ratio & & & $\begin{array}{c}-6.48 * * * \\
{[0.65]}\end{array}$ & $\begin{array}{c}-6.53^{* * *} \\
{[0.64]}\end{array}$ \\
\hline Beta & & & $\begin{array}{l}3.25^{* *} \\
{[1.28]}\end{array}$ & $\begin{array}{l}3.11^{* *} \\
{[1.26]}\end{array}$ \\
\hline Momentum & & & & $\begin{array}{c}0.19 * * * \\
{[0.028]}\end{array}$ \\
\hline Constant & $\begin{array}{c}-23.07 * * * \\
{[1.80]}\end{array}$ & $\begin{array}{c}-50.33 * * * \\
{[3.01]}\end{array}$ & $\begin{array}{c}-48.00 * * * \\
{[3.56]}\end{array}$ & $\begin{array}{c}-47.92 * * * \\
{[3.52]}\end{array}$ \\
\hline Observations & 2660 & 2660 & 2327 & 2327 \\
\hline R-squared & 0.01 & 0.08 & 0.13 & 0.15 \\
\hline
\end{tabular}

Notes: Standard errors in brackets; ***, **, and * denote p-value less than $1 \%, 5 \%$, and $10 \%$, respectively. Stock return, financial constraint, external finance dependence and demand sensitivity are winsorized at the $2 \%$ level. 
Table 4: Does Liquidity Constraint Explain Changes in Stock Prices During September 10-28, 2001?

\begin{tabular}{lcc}
\hline & 1 & 2 \\
Firm Size & -0.17 & -0.45 \\
& {$[0.13]$} & {$[0.34]$} \\
Book/Market Ratio & $-0.38^{* * *}$ & $-0.38^{* * *}$ \\
& {$[0.074]$} & {$[0.08]$} \\
Firm Beta & $-5.49^{* * *}$ & $-5.33^{* * *}$ \\
& {$[0.48]$} & {$[0.49]$} \\
Momentum & $2.57^{* * *}$ & $2.51^{* * *}$ \\
& {$[0.54]$} & {$[0.55]$} \\
Financial Constraint & & -0.59 \\
$\quad$ Whited-Wu index, 2000 value) & & {$[0.68]$} \\
Constant & $-7.21^{* * *}$ & $-7.14^{* * *}$ \\
& {$[0.82]$} & {$[0.83]$} \\
Observations & 4678 & 4563 \\
R-squared & 0.04 & 0.04 \\
\hline
\end{tabular}

Notes: Standard errors in brackets; ***, **, and * denote p-value less than $1 \%, 5 \%$, and $10 \%$, respectively. Stock return, financial constraint, external finance dependence and demand sensitivity are winsorized at the $2 \%$ level. 
Table 5: Placebo Tests: Stock Price Changes Before the Subprime Crisis (June 30-July 31, 2007)

\begin{tabular}{lccc}
\hline & 1 & 2 & 3 \\
Demand Sensitivity & -0.26 & 0.03 & 0.05 \\
& {$[0.22]$} & {$[0.23]$} & {$[0.23]$} \\
Financial Constraint & 0.06 & -0.56 & -0.37 \\
(Whited-Wu index) & {$[0.22]$} & {$[0.62]$} & {$[0.62]$} \\
Firm Size & & -0.06 & -0.01 \\
& & {$[0.31]$} & {$[0.30]$} \\
Book/Market ratio & $-0.95^{* * *}$ & $-1.00^{* * *}$ \\
& & {$[0.17]$} & {$[0.17]$} \\
Beta & $-1.03^{* * *}$ & $-1.04^{* * *}$ \\
& & {$[0.33]$} & {$[0.33]$} \\
Momentum & & $0.02^{* * *}$ \\
& & {$[0.01]$} \\
Constant & $-5.15^{* * *}$ & $-4.69^{* * *}$ & $-4.72^{* * *}$ \\
& {$[0.64]$} & {$[0.82]$} & {$[0.82]$} \\
Observations & 2760 & 2409 & 2409 \\
R-squared & 0 & 0.02 & 0.02 \\
\hline Notes: Standard errors in brackets; ***, **, and * denote p-value less than $1 \%, 5 \%$, and $10 \%$, \\
respectively.
\end{tabular}




\section{Table 6: Adding Exposures to Exchange Rate and Commodity Price Movement} Stock price change during the Subprime Crisis, 7/31/07-3/31/08

\begin{tabular}{|c|c|c|c|c|}
\hline & 1 & 2 & 3 & 4 \\
\hline Demand Sensitivity & $\begin{array}{c}-3.02 * * * \\
{[0.87]}\end{array}$ & $\begin{array}{c}-2.98 * * * \\
{[0.90]}\end{array}$ & $\begin{array}{c}-3.22^{* * *} \\
{[0.87]}\end{array}$ & $\begin{array}{c}-3.18^{* * *} \\
{[0.90]}\end{array}$ \\
\hline Financial Constraint (WW index) & $\begin{array}{c}-12.01 * * * \\
{[2.31]}\end{array}$ & $\begin{array}{c}-10.75^{* * *} \\
{[2.51]}\end{array}$ & $\begin{array}{c}-12.40^{* * *} \\
{[2.31]}\end{array}$ & $\begin{array}{c}-11.06^{* * *} \\
{[2.51]}\end{array}$ \\
\hline Firm Size & $\begin{array}{c}0.27 \\
{[1.13]}\end{array}$ & $\begin{array}{c}0.24 \\
{[1.16]}\end{array}$ & $\begin{array}{c}-0.08 \\
{[1.13]}\end{array}$ & $\begin{array}{c}-0.09 \\
{[1.16]}\end{array}$ \\
\hline Book/Market Ratio & $\begin{array}{c}-6.32 * * * \\
{[0.63]}\end{array}$ & $\begin{array}{c}-6.42^{* * *} \\
{[0.64]}\end{array}$ & $\begin{array}{c}-6.39 * * * \\
{[0.63]}\end{array}$ & $\begin{array}{c}-6.50^{* * * *} \\
{[0.64]}\end{array}$ \\
\hline Beta & $\begin{array}{c}1.10 \\
{[1.29]}\end{array}$ & $\begin{array}{c}1.32 \\
{[1.32]}\end{array}$ & $\begin{array}{c}1.51 \\
{[1.30]}\end{array}$ & $\begin{array}{c}1.64 \\
{[1.32]}\end{array}$ \\
\hline Momentum & $\begin{array}{c}0.19^{* * *} \\
{[0.03]}\end{array}$ & $\begin{array}{c}0.18^{* * *} \\
{[0.03]}\end{array}$ & $\begin{array}{c}0.20^{* * *} \\
{[0.03]}\end{array}$ & $\begin{array}{c}0.19^{* * *} \\
{[0.03]}\end{array}$ \\
\hline Exposure to Euro & $\begin{array}{l}16.46 \\
{[12.0]}\end{array}$ & $\begin{array}{l}16.95 \\
{[12.2]}\end{array}$ & $\begin{array}{l}-10.6 \\
{[18.5]}\end{array}$ & $\begin{array}{l}-7.87 \\
{[18.9]}\end{array}$ \\
\hline Exposure to Yen & $\begin{array}{c}2.30 \\
{[10.6]}\end{array}$ & $\begin{array}{l}-0.37 \\
{[10.8]}\end{array}$ & $\begin{array}{c}4.65 \\
{[18.1]}\end{array}$ & $\begin{array}{l}-1.55 \\
{[18.5]}\end{array}$ \\
\hline Exposure to Energy & $\begin{array}{c}0.67 * * * \\
{[0.15 .]}\end{array}$ & $\begin{array}{c}0.65^{* * *} \\
{[0.15]}\end{array}$ & $\begin{array}{c}0.82^{* * *} \\
{[0.19]}\end{array}$ & $\begin{array}{c}0.83^{* * *} \\
{[0.19]}\end{array}$ \\
\hline Exposure to Metal & $\begin{array}{c}-15.23 * * \\
{[6.12]}\end{array}$ & $\begin{array}{c}-14.13^{* *} \\
{[6.27]}\end{array}$ & $\begin{array}{c}-4.87 \\
{[8.68]}\end{array}$ & $\begin{array}{l}-3.52 \\
{[8.91]}\end{array}$ \\
\hline Exposure to Agriculture & $\begin{array}{c}-0.16 \\
{[0.11]}\end{array}$ & $\begin{array}{c}-0.18 \\
{[0.11]}\end{array}$ & $\begin{array}{c}-0.38^{* *} \\
{[0.19]}\end{array}$ & $\begin{array}{c}-0.42^{* *} \\
{[0.19]}\end{array}$ \\
\hline Financial Constraint (RZ index) & & $\begin{array}{c}-5.01 * * \\
{[1.99]}\end{array}$ & & $\begin{array}{c}-5.21^{* * *} \\
{[1.99]}\end{array}$ \\
\hline $\begin{array}{l}\text { Financial Constraint* } \\
\text { External Finance Dependence }\end{array}$ & & $-2.49 * * *$ & & $-2.53 * * *$ \\
\hline Constant & $\begin{array}{c}-51.47^{* * *} \\
{[3.15]}\end{array}$ & $\begin{array}{c}{[0.84]} \\
-48.22^{* * *} \\
{[3.57]}\end{array}$ & $\begin{array}{c}-50.31 * * * \\
{[3.12]}\end{array}$ & $\begin{array}{c}{[0.84]} \\
-46.89 * * * \\
{[3.54]}\end{array}$ \\
\hline Observations & 2408 & 2325 & 2408 & 2325 \\
\hline R-squared & 0.15 & 0.16 & 0.15 & 0.16 \\
\hline
\end{tabular}

Note: The exposures to exchange rates and commodity prices are constructed following a two-step procedure. In Step 1, for each firm, we regress its weekly stock returns on the S\&P 500 market return, percentage changes in the euro-dollar exchange rate and the yen-dollar exchange rate, and percentage changes in three commodity groups' spot price indexes (energy, agriculture, and metal) during 2004 to 2006. We collect the five estimated coefficients on the exchange rates and the commodity prices for each firm. In step 2, we multiple these coefficients individually with the realized percentage changes for these exchange rates and commodity price indexes over July 31, 2007-March 30, 2008. These are firm-level ex post exposures to major currencies and commodity prices used in Columns 1 and 2. In Columns 3 and 4, we use an alternative definition of exposures in which all statistically insignificant coefficients in Step 1 are assigned a zero value. 


\section{Figure 1: The Log of Stock Index during Subprime Crisis}

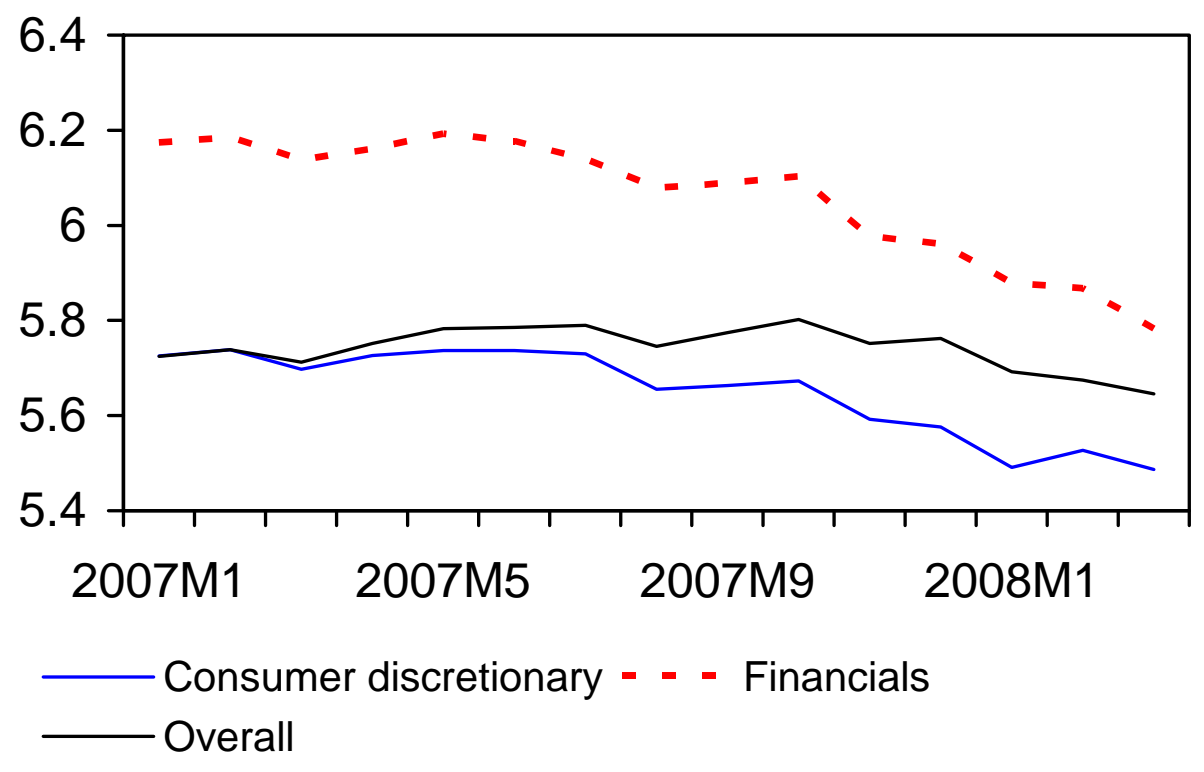

\section{Figure 2: News Count of "Subprime” and “Crisis"}

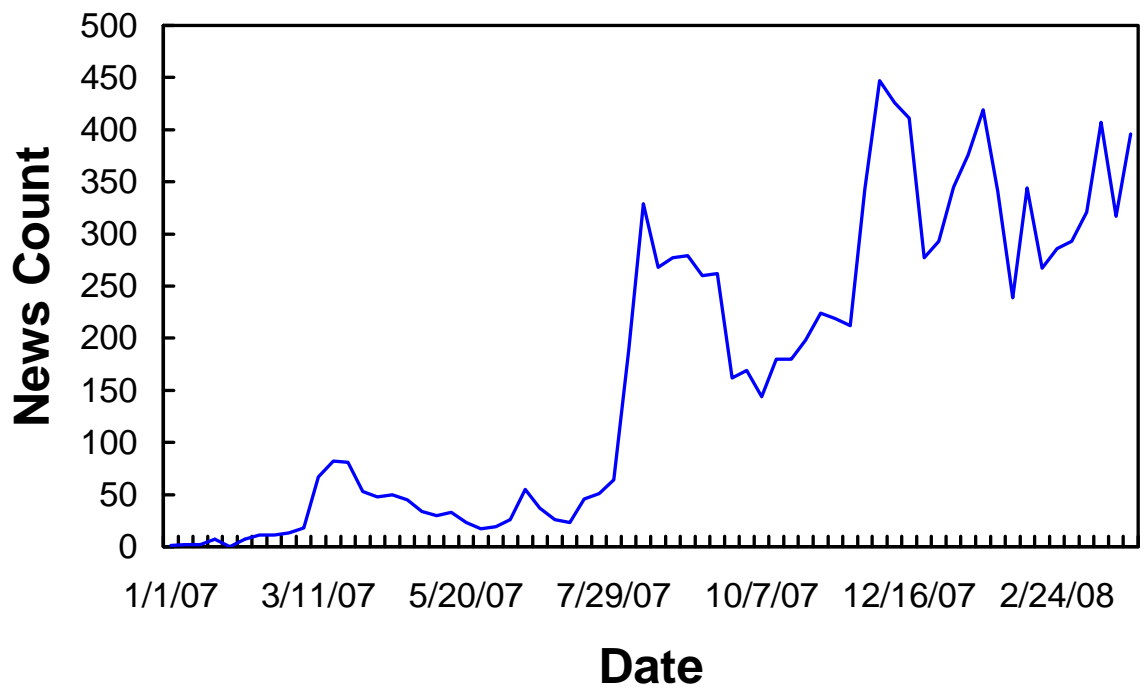

This graph reports a weekly count of news articles containing the words "subprime" and "crisis" in all US newspapers, excluding republished news, recurring pricing and market data. A week is defined as from Sunday to Saturday. The count was 64 for the week of July 29th, 189 for the week of August 5th, and 329 for the week of August 12, 2007, respectively. Source: Factiva. 


\section{Figure 3: Consensus Forecast of US Real GDP Growth}

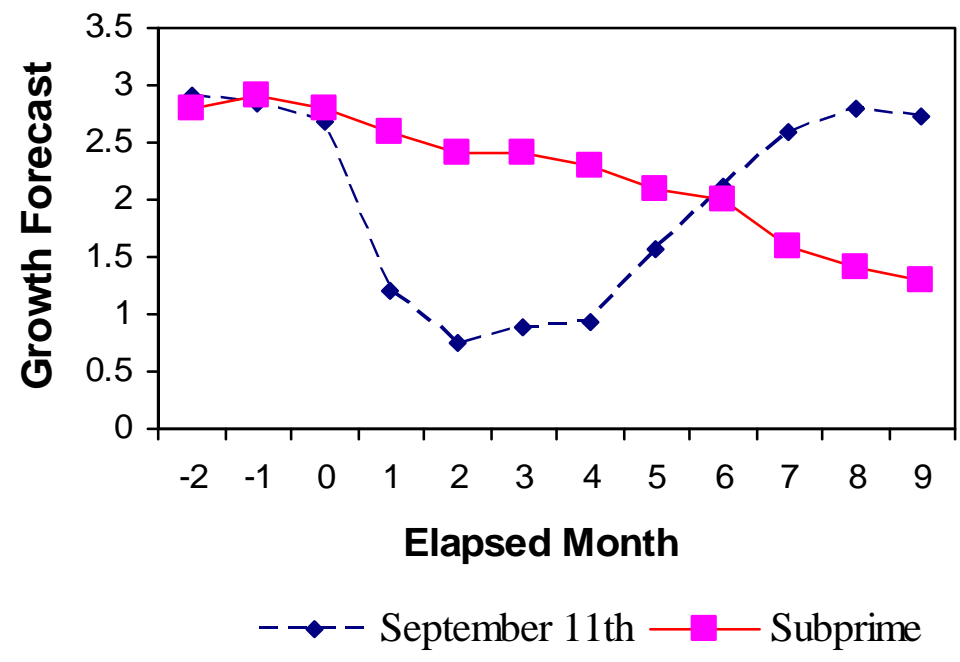

The two lines trace forecast of annual GDP growth for the calendar year of 2002 and 2008, respectively

Figure 4: Consumer Confidence around Sept $11^{\text {th }}$ and Subprime Crisis Source: University of Michigan Consumer Expectation Survey

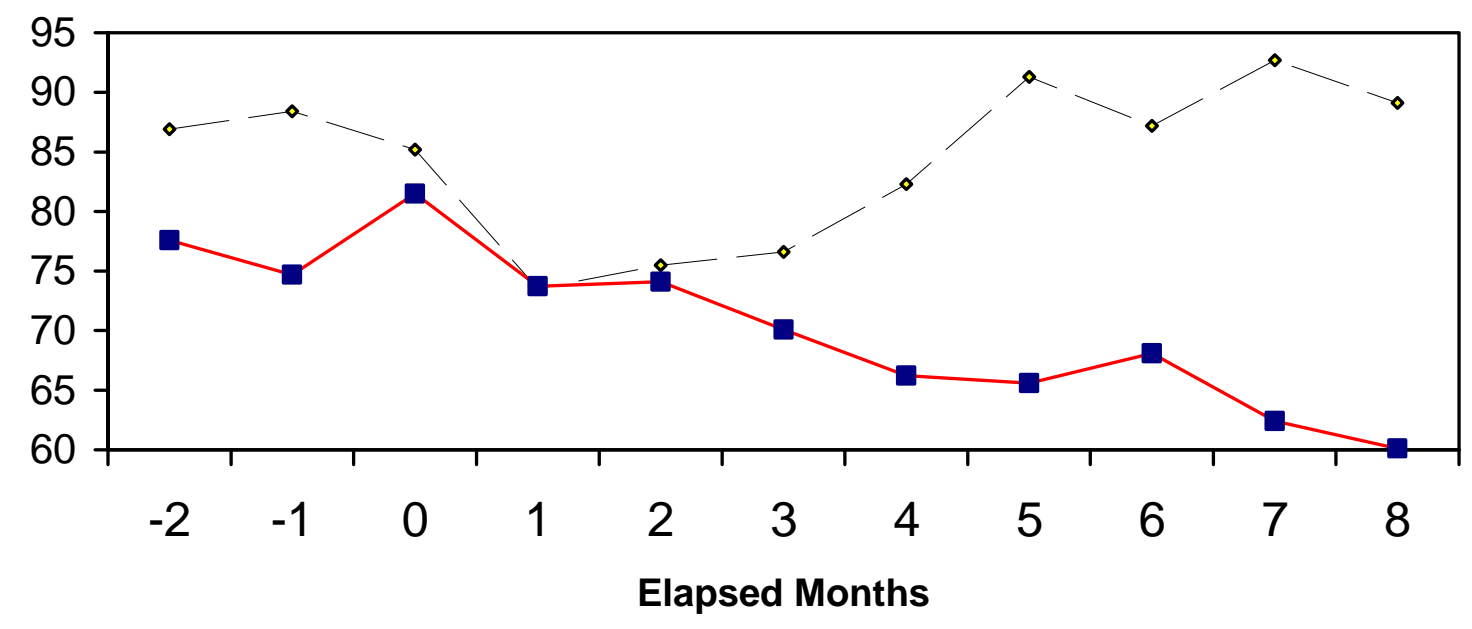

$\longrightarrow-$ September 11th $\longrightarrow$ Subprime 
Figure 5: TED (Euro-dollar bond over Treasury Bond) spread around September $11^{\text {th }}$ and Subprime Crisis

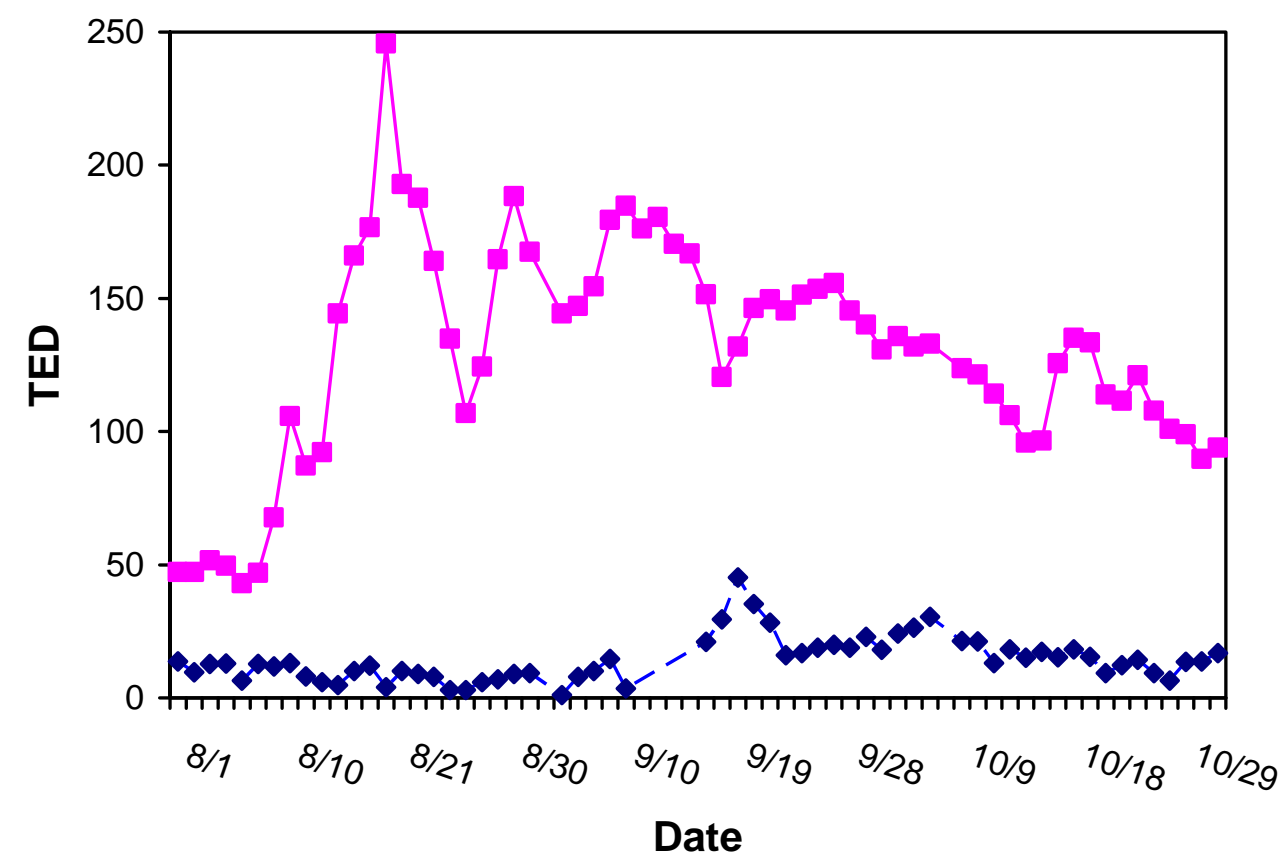

- - TED--September 11 (2001)

$\longrightarrow$-TED_Subprime Crisis (2007) 
Figure 6: Cumulative Stock Returns Since August 2007

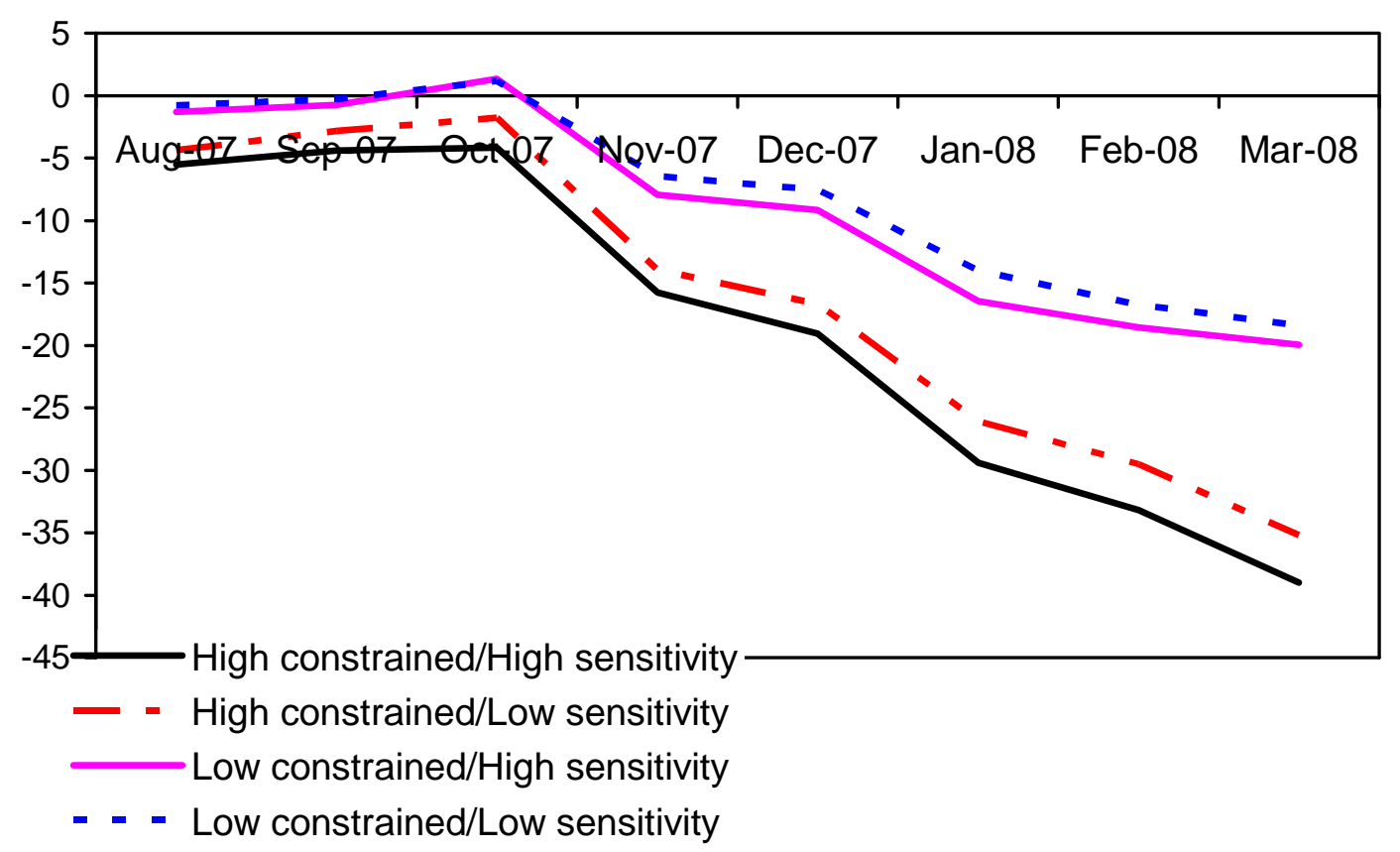


Figure 7: Key Regression Coefficients from Successively Expanding Samples

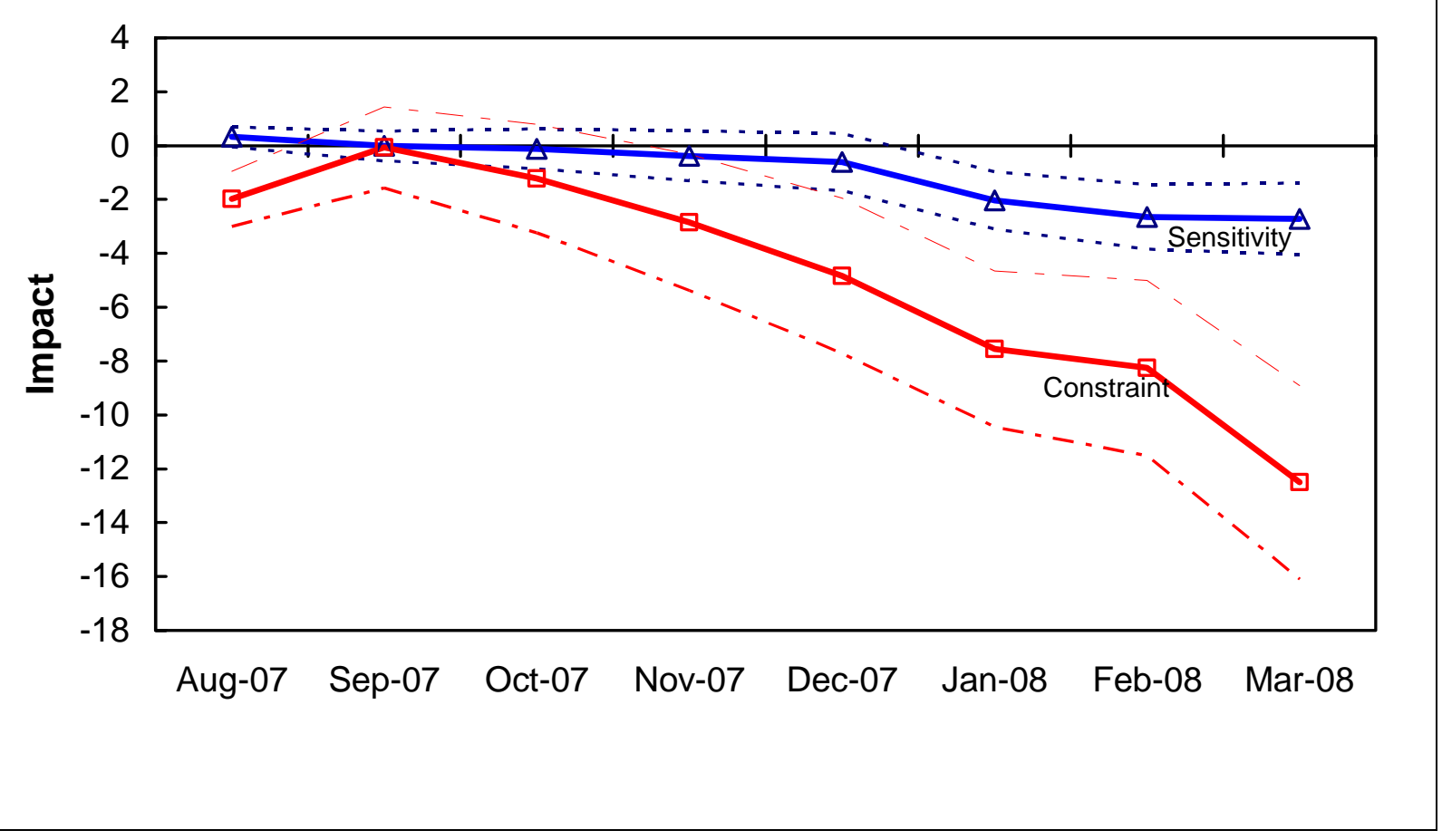

